\title{
Experimental Study of the Drilling Process in Debris-Rich Ice
}

\author{
Pinlu $\mathrm{Cao}^{1}$, Cheng Yang ${ }^{1}$, Yunwang $\mathrm{Chen}^{1}$, Baoyi $\mathrm{Chen}^{2}$, Pavel Talalay ${ }^{1}$ \\ 1. Polar Research Center, Jilin University, No. 938 Ximinzhu Str., Changchun City130061, China \\ 2.College of Construction Engineering, Jilin University, No.938 Ximinzhu Str., Changchun City 130061, China \\ Correspondence to: Pavel Talalay (ptalalay@yahoo.com)
}

\begin{abstract}
Debris-rich ice is often encountered when drilling into basal ice and rock glaciers. The standard steel
\end{abstract} bits used for ice core drilling are not suitable because the cutters are very easily broken by rock particles because their hardness and abrasiveness are higher than that of the ice. The tool steel and tungsten carbide inserts are easily damaged in intermixed ice-rock formations. To obtain high-quality core samples in debris-rich ice, it is necessary to find drill bits that can drill ice-rock mixtures with minimal load and acceptable penetration rate and torque. A special testing stand has been designed and constructed to study both standard and custom-made carbide and polycrystalline diamond compact (PDC) drill bits. The results show that both the carbide and the PDC drill bits can drill with high penetration rates in debris-rich ice containing very hard and abrasive granite particles at low drill loads of 500-1200 N. When the rock volume content is $30 \%$, the penetration rates are $4.68 \mathrm{~m} / \mathrm{h}, 5.9 \mathrm{~m} / \mathrm{h}$ and 11.12 $\mathrm{m} / \mathrm{h}$ for the standard six-tooth carbide drill bit, a PDC bit with a round compact and a PDC bit with a semi-round compact, respectively, under a drill load of $500 \mathrm{~N}$ with a rotation speed of $100 \mathrm{rpm}$. Within the range of drill loads of 500 to $1200 \mathrm{~N}$ and rotation speeds of 50 to $200 \mathrm{rpm}$, the maximum torque is no more than $45 \mathrm{Nm}$, and the power consumption is less than $0.8 \mathrm{~kW}$. In addition, the temperature changes of the bit cutters caused by their cutting action were also measured. Results of the preliminary tests show that temperature variations increase from 3.67 to $5.96{ }^{\circ} \mathrm{C}$ when the drill load increases from 450 to $1200 \mathrm{~N}$ and from 4.17 to $6.21{ }^{\circ} \mathrm{C}$ when the rotation speed increases from 50 to $200 \mathrm{rpm}$.

Key words: Ice drilling; PDC drill bit; Carbide drill bit; Ice-rock mixing material

\section{Introduction}


Drilling into basal ice, till and bedrock has garnered much scientific interest because it offers unique opportunities to research subglacial environments, basal morphology and tectonics and the subglacial hydraulic system (Hansen et al., 2010). Samples of subglacial material not only contain important records of ice sheet history and climate change but also give significant information about ice-sheet/bedrock interaction and how this zone influences the overlying ice sheet dynamics (Popp et al., 2014). Moreover, there are may be existing biological activity within the ice sheets or in the basal materials. However, the ice located in this zone is extremely difficult to drill because it is often loaded with debris and rock and may have particles of various sizes in it, ranging from clay and silt to pebbles, cobbles and boulders (Talalay, 2013). For example, till obtained from three of the four holes drilled to investigate the subglacial conditions of the Black Rapids Glacier in the central Alaska Range in 1998 contained gabbro and amphibolite inclusions in the form of sand, gravel and pebbles (Truffer et al., 1999). One of the challenges of drilling in these environments is that the ice can be near the pressure melting point so liquid water may be present already despite additional heat produced by the drilling itself. For example, in 2006-07 drilling season at Dome F, Antarctica in approach to the ice sheet basement extra fine particles of frozen water appeared in the chip chamber, and frozen water chips accumulated on the ice core top (Motoyama, 2007). It was concluded that water beneath the ice sheet had probably leaked into the borehole and had frozen at the bottom. Some parts of the drill were covered with ice and dripping water froze at the open face of the core and drill head. The basal ice core contained small rock particles.

Another challenging scientific problem is related to the study of rock glaciers - ice-rock mixtures moving downslope or true glaciers covered by rock debris in polar and mountain regions (Haeberli et al., 2006). Relatively few boreholes have been drilled into and through rock glaciers to permit investigation of thermal and other characteristics of the deeper subsurface. Although good progress has been made in the development of special drilling equipment for coring in rock glaciers, many problems still need to solved, especially in the areas of the production of reliable drill bits and the elimination of heat generated in the hole (Green et al., 2007). 
The most effective method for penetrating subglacial sediments and bedrock is electromechanical cable-suspended drilling technology. Even the bit load produced by the drill weight is usually within the range $1.5-4 \mathrm{kN}$, and the rotation speed of the drill is normally in the range of 50 to $120 \mathrm{rpm}$ (Augustin, 2007), there have been several successful attempts to drill into debris layers in basal ice. In 1966, in the hole at Camp Century, Greenland, subglacial materials consisting of frozen till and various sizes of rocks were encountered at the depth of $1387.5 \mathrm{~m}$. The penetration rate decreased to $1.5 \mathrm{~m} / \mathrm{h}-2.2 \mathrm{~m} / \mathrm{h}$, the drilling pressure increased to $8 \mathrm{kN}$, and the power consumption rose to $16 \mathrm{~kW}$ when drilling in this stratum (Ueda and Garfield, 1968). From 1989 to 1992, an updated version of the ISTUK drill was used to drill into subglacial bedrock in Dye-3 at Summit, Greenland. Drilling was stopped at a depth of $3028.8 \mathrm{~m}$ because the cutting knives of the drill head were damaged by hitting gravel and stones. Subglacial material containing both embedded debris-containing and clear ice layers was obtained. Minor pebbles up to approximately $1 \mathrm{~cm}$ in length were present in this material (Talalay, 2013). In 1988, the Russian KEMS-135 electromechanical drill was used for core drilling on Vavilov Glacier. The boundary between glacier and bedrock was at a depth of $459.33 \mathrm{~m}$. The average penetration rate was approximately $1.6 \mathrm{~m} / \mathrm{h}$, and the average length of run was $0.37 \mathrm{~m}$ when drilling in subglacial material. A $2.28 \mathrm{~m}$ subglacial core was retrieved, which was characterized by less than $50 \%$ ice content and by structures and textures typical of permafrost. Mineral materials included red-brown siltstones, sandstones and mudstones (Kudryashov et al., 1994). The PICO-5.2" electromechanical drill was successfully used for core drilling to bedrock at the GISP2 Summit site in central Greenland in 1993 (Gow and Meese, 1996). Debris-rich ice encountered at $3040.34 \mathrm{~m}$ depth consisted predominantly of fine-grained amber- to brown-colored sediment, mainly silt with some sand and occasional lithic particles up to $2 \mathrm{~cm}$ in diameter. In the 2011 and 2012 seasons, the Hans Tausen drill with a concrete diamond core bit was used to penetrate subglacial coarse material in the NEEM deep drilling project. Several meters of core containing subglacial sediments, rocks and rock fragments were collected, as well as embedded stones up to $2 \mathrm{~cm}$ in diameter (Popp et al., 2014). 
The subglacial drilling practice has demonstrated that the standard steel bit used for ice core drilling is not suitable for basal debris-rich ice drilling; the cutters are very easily broken by rock particles because their hardness and abrasiveness are higher than that of the ice. Several studies have been conducted to investigate diamond bits for subglacial bedrock drilling. Wang and others tested different diamond bits in rock samples with medium to high drillability at most VIII-IX grades (Wang et al., 1999). To drill hard rocks, Cao and others tested both standard diamond bits and bionic bits in granite rock samples with drillabilities in the range of grades X-XI (Cao et al., 2014). However, these drill bits cannot be used to drill ice-rock mixtures. Sellmann et al. designed and tested many types of auger bits to drill fine-grained soils such as frozen silt and sand (Sellmann and Mellor, 1986; Sellmann and Brockett, 1988). They concluded that the drill bits needed to stay sharp as long as possible in order to obtain the acceptable penetration rate. Saito and Yoshikawa (2008) researched the portable drilling technology used to drill frozen coarse-grained material, such as frozen gravel. More than 20 different auger/core bits were designed and tested in their study, including several different shapes of core bits with carbide and diamond chips, but these auger bits cannot be used in electromechanical drilling technology. Green and others (2007) designed special cutters with tool steel and tungsten carbide inserts for drilling in ice with small rocks. The tool steel inserts did not perform as well as expected; they were easily damaged and wore out quickly. The tungsten carbide inserts also often became chipped and dull. Similarly, carbide inserts on steel cutters were also experimented with in the subglacial environment at NEEM, with similar poor performance characterized by chipping and dulling when encountering rock fragments (Popp et al., 2014). Together with the experience of Green and others (2007), such an approach can be safely discarded.

The outstanding feature of electromechanical cable-suspended drilling technology is that the bit load produced by the drill weight is usually within the range $1.5-4 \mathrm{kN}$, and the rotation speed of the drill is normally in the range of 50 to $120 \mathrm{rpm}$ (Augustin, 2007). Taking into consideration the limitations of the bit load and rotation speed available in most electromechanical drills, in this study, standard and custom-made carbide and PDC drill bits for 
drilling ice-rock mixing material with minimal load and rotation speed are tested.

\section{Testing equipment}

\subsection{Testing stand}

The testing stand consists of an OB-330 motor fixed on a frame, an oil cylinder, a steel box, a circulation pump, a mud tank and a control system with various sensors, as shown in Fig. 1. The samples of ice-rock mixtures being tested, with sizes of approximately $300 \times 300 \times 250 \mathrm{~mm}$, are fixed in the steel box using two strong screw-bolts. An oil cylinder with a maximum stroke of $450 \mathrm{~mm}$ is used to drive the steel box up and down. The pressure of the oil being pumped from the hydraulic system to the oil cylinder is adjusted by the proportional relief valve on the control panel of the hydraulic system within the range of 0 to $16 \mathrm{MPa}$. This means that the maximum axial force can reach $50 \mathrm{kN}$. The low temperature drilling fluid is circulated by the SUROM centrifugal pump with a maximum flow rate of $40 \mathrm{~L} / \mathrm{min}$.

Several parameters, including the drill bit load, the rotation speed, the torque, the penetration depth, the rate and the power consumption are continuously measured and recorded at one second intervals during drilling runs. Two SSI-P50-type pressure sensors installed in the upper and lower chambers of the oil cylinder are used to measure the oil pressure. Then, the axial force is estimated by dividing the pressure difference between the upper and lower oil chambers by the cross-sectional area of the piston rod. Taking into account the weight of the ice-rock mixture samples and the steel box, the load on the drill bit can be calculated.

An LKN-200-type torque sensor, installed between the motor axis and the swivel, is used to measure the torque, the power consumption and the rotation speed of the drill bit. The measuring limit for the torque and the rotation speed is approximately $200 \mathrm{Nm}$ and $1000 \mathrm{rpm}$, respectively.

A WEP-50 drawstring displacement sensor is installed on the shell of the oil cylinder, and the end of the drawstring is fixed on the body of the steel box. The sensor measures the length of the drill run, and the relative displacement is converted into the penetration rate. 
All data are transmitted and stored in the computer, and the main parameters can be displayed in graphic form on the screen.

\subsection{Drilling bits}

Three standard and custom-made drill bits (Fig. 2) are used to core the ice-rock mixing material, including:

A - a standard carbide bit with six octagonal cutters, which is used to drill hard rocks with drillability of grades

IV-VIII in geological drilling (Wang et al, 2014);

B - a standard PDC bit with four round PDC cutters with a diameter of $12.5 \mathrm{~mm}$;

$\mathrm{C}$ - a custom-made PDC bit with four semi-round PDC cutters with a width of $9.5 \mathrm{~mm}$.

The carbide cutters are inserted on the body of the drill bit with a rake angle of $0^{\circ}$ and a relief angle of $25^{\circ}$. The rake angle $\left(-15^{\circ}\right)$ and the relief angle $\left(15^{\circ}\right)$ are the same for both PDC drill bits. The basic parameters of the tested drill bits are given in Table 1. For these three drill bits, the clearance between the drill bit body and the borehole wall are $1 \mathrm{~mm}, 2.5 \mathrm{~mm}$ and $1 \mathrm{~mm}$, respectively. Core catchers were not used in the drill head because the purpose of the testing is to study the cutting process only.

\subsection{Specimen preparation}

There are two types of ice-rock mixture specimens used in the tests, as shown in Fig. 3. The rock volume content of the first one is $\sim 10 \%$, and there is no contact between the rock particles. The second specimen contains $\sim 30 \%$ rock volume, and the particles are settled together. The tested samples with dimensions of $\sim 250 \times 150 \times 350$ $\mathrm{mm}$ are frozen layer by layer in a special freezing chamber at a temperature of $-20{ }^{\circ} \mathrm{C}$. The thickness of each layer is $\sim 15 \mathrm{~mm}$, and the rock particles are evenly distributed in it.

Granite with high quartz content was selected as the debris in this study. The rock drillability is in the range of grades X-XI. A stone crusher was used to crush the large rocks into granules, and particles with sizes of 5 to 10 mm were selected to make the frozen ice-rock mixture specimens.

\subsection{Operating parameters and testing procedure}


Depending on the mechanical properties of the rock to be drilled, the recommended drill load for the carbide drill bit with six octagonal cutters is in the range of 5 to $10 \mathrm{kN}$, and it is approximately 3 to $5 \mathrm{kN}$ for PDC drill bits with four compacts (Wang et al, 2014). Considering that the load on the bit is produced by the drill weight of the cable-suspended drill, the tests are conducted with loads as low as $0.5-1.25 \mathrm{kN}$.

The fundamental mechanism of rock fragmentation induced by both the carbide drill bit and the PDC bits is shear failure, which is very similar to the shearing mechanism in the metal-cutting process. Therefore, the rotation speed applied to the drill bit is one of the most important variables to increase the penetration rate for both carbide and PDC bits. The rotation speed for these drill bits is recommended to be in the range of 150 to $600 \mathrm{rpm}$. Here, the rotation speed was chosen to be as low as 50 to $200 \mathrm{rpm}$.

The circulation of low temperature drilling fluid with an adequate rate of flow is extremely important when drilling frozen ice and rock mixtures. If cuttings are produced more rapidly than they are removed, they will be reground by the drill bit. This process not only slows the penetration rate but also raises the temperature of the drill bit cutters, both of which further deteriorate the drilling conditions. Kerosene was used as the drilling fluid in all of the tests, and the flow rate was $\sim 40 \mathrm{~L} / \mathrm{min}$.

All experiments were conducted in a cold room at a temperature of $-5{ }^{\circ} \mathrm{C}$. The depth of each hole was 250 to 300 $\mathrm{mm}$, and each test was performed twice to reduce possible experimental errors.

\section{Results and discussion}

\subsection{Penetration rate}

Due to the difference in hardness and strength between ice and rock, the penetration rate is very fast in pure ice, and it is slowed when the drill bits meet rock pieces under the same conditions. Therefore, the instantaneous penetration rate and torque fluctuate greatly when drilling in such inhomogeneous ice-rock mixtures. Fig. 4 shows the instantaneous penetration rate and cutting torque variations of the carbide drill bit with a rotation speed of 100 rpm and four different drill loads from 580 to $1155 \mathrm{~N}$ in the course of drilling samples with a rock volume content 
of $10 \%$. As an example, at a load of $580 \mathrm{~N}$ the penetration rate varies in the range of 0.95 to $2.38 \mathrm{~mm} / \mathrm{s}$ and the torque jumps from 1.5 to $23 \mathrm{Nm}$.

The relationship between the average penetration rate and the drill load was studied at a fixed rotation speed of the drill bit (100 rpm) (Fig. 5a). Here, the penetration rate is estimated as the mean value during the coring run. The depth to which the cutter pierced into the ice-rock mixture increases with increases of the drill load, so the drilling speed increases greatly for all three drill bit types. The cutters of drill bit A are sharper than those of the other bits, and the bit has a greater number of cutters. Therefore, the axial force applied to each cutter of drill bit A is lower than that for drill bits $\mathrm{B}$ and $\mathrm{C}$ at the same drill load conditions. Thus, the penetration rate of drill bit $\mathrm{A}$ is far slower than that of the others. When the rock content is $10 \%$, the penetration rate for drill bit A increases from 1.38 to $3.07 \mathrm{~mm} / \mathrm{s}$ with the increase of the drill load, while for drill bits B and C it increases from 4.83 to 15.17 $\mathrm{mm} / \mathrm{s}$ and from 3.97 to $13.42 \mathrm{~mm} / \mathrm{s}$, respectively. In addition, the penetration rates of the drill bits decrease considerably with increasing rock content in the ice-rock mixture. It is notable that the penetration rate of drill bit $\mathrm{C}$ is higher than that of drill bit B when the rock content is $30 \%$ at any given drill load, whereas the results are opposite when the rock content is $10 \%$ and the drill load is more than $800 \mathrm{~N}$. These results may be attributed to the difference between the compact shapes and sizes of drill bits B and C. The other reason may be that the mechanical properties of the samples are slightly different, as the rock size and its distribution in the samples are not exactly the same.

The effect of rotation speed on penetration rate was studied by maintaining a constant load on the bit of $1000 \mathrm{~N}$. The results are presented in Fig. 5b. The penetration rate increases with an increase of the rotation speed and decreases with a reduction of the rock content in the ice-rock mixing materials for all three drill bit types. Moreover, when the rock content is $10 \%$, the penetration rates of the drill bits $\mathrm{B}$ and $\mathrm{C}$ are almost the same at lower rotation speed. When the rotation speed exceeds $100 \mathrm{rpm}$, the penetration rate of the drill bit $\mathrm{C}$ is higher than that of the drill bit B. 


\subsection{Torque moment}

The drill load has a strong influence on the cutting torque, as presented in Fig. 6. It was found that the cutting torque increases with increasing drill load and decreases with a decrease of the rock content in the ice-rock mixture. Both the maximum and average torque on drill bit A are lower than those on the other two drill bits.

With the drill load increasing from 500 to $1200 \mathrm{~N}$, the average torque increases from 12.25, 9.57 and $17.38 \mathrm{Nm}$ to $22.78,25.2$ and $21.24 \mathrm{Nm}$ for drill bit $\mathrm{A}, \mathrm{B}$ and $\mathrm{C}$, respectively, in the course of drilling samples with $30 \%$ rock content. In the same circumstances, the maximum torque increases correspondingly from $22.82,19.42,28.4 \mathrm{Nm}$ to 34.84, 36.94, $42.39 \mathrm{Nm}$ for drill bit A, B and C, respectively. Surprisingly, the maximum torque of drill bit C decreases with increasing rock volume content. Most likely, this effect is connected with inhomogeneity of the sample materials.

With increases of the rotation speed, the cutting torque of drill bit $\mathrm{C}$ remains almost the same, while it decreases slightly for drill bit B for all samples (Fig. 7). Even though high rotation speed can cause drilling instability, increasing rotation speed should take priority from the torque point of view over increasing drill load when the penetration rate needs to be improved because this can reduce the anti-torque system burden of the electromechanical drills.

\subsection{Consumed power}

The relationship between power consumption and drill load with a constant rotation speed of $100 \mathrm{rpm}$ is shown in Fig. 8. It can be seen that the power consumed during cutting increases gradually with an increase of the drill load. Meanwhile, the more rock particles there are in the ice-rock mixture, the more power that is consumed. Within the range of the tested loads, the average power consumption values for the three types of drill bits are no more than $0.25 \mathrm{~kW}$, and the maximum values are less than $0.45 \mathrm{~kW}$.

The power consumption of all three drill bits increases rapidly with an increase of rotation speed (Fig. 9). Although the penetration rate of the carbide drill bit A is far lower than that of the PDC bit B, the consumed power 
is almost the same. If the rotation speed is $200 \mathrm{rpm}$, the maximum power consumption is approximately $0.61,0.72$ and $0.79 \mathrm{~kW}$ for drill bits A, B and C, respectively, in the case of drilling samples with $30 \%$ rock content. The output power of the driven motors of existing electromechanical drills is typically up to $2.2 \mathrm{~kW}$ (Talalay, 2003). Therefore, the power consumed drilling in the ice-rock mixture is acceptable.

\subsection{Cutting temperature}

A major part of the total energy spent during rotation drilling is lost as frictional heat (Loui and Karanam, 2005).

The temperature rise caused by this frictional heat has a significant effect on the drilling process. While drilling ice and frozen ground, drill bit heating can result in ice chips melting, causing the chips to get stuck (Azuma et al., 2007). This ice buildup prevents further penetration, reduces core quality and greatly increases the likelihood of the drill becoming stuck (Gundestrup et al., 2002). The temperature rise generated by drilling in ice-rock mixtures would be higher than that generated by drilling in pure ice, due to present of the rocks in the materials and the larger amount of frictional heat. Drilling in rock glaciers showed that the friction on the drill bit produced enough heat to prevent the water from freezing as long as drilling continued (Green et al., 2007). Therefore, care should be taken to minimize the heat generated in the hole because such heat can cause the drill to freeze in the hole. If the drill starts to freeze, the drill motor requires more power. If the drill stops turning, it will freeze instantly.

There are many factors that can affect the temperature rise, including drill bit type, cutter shape and size, drilling parameters and so on (Che et al, 2012). In the current study, the preliminary tests to measure the cutting temperature were conducted using a PDC drill bit with the same structural parameters as drill bit B except for the wall thickness of the bit crown. To install the thermometer, the thickness of the crown was increased to $6 \mathrm{~mm}$ instead of the standard thickness of 3.5- $4 \mathrm{~mm}$.

A platinum resistance thermometer with an accuracy of $\pm 0.01^{\circ} \mathrm{C}$ was inserted into a 3-mm diameter hole drilled at a distance approximately $4 \mathrm{~mm}$ from the cutting edge of the PDC cutter. Silicone grease was used as the heat conducting medium, and glass glue was used to ensure a good seal. Kerosene was used as the drilling fluid, with a 
flow rate of $40 \mathrm{~L} / \mathrm{min}$. The ice-rock mixture with a rock volume content of $30 \%$ was prepared for this testing. All experiments were performed outdoors. Hence, the initial temperatures of the testing stand, cutters, ice-rock mixture samples and drilling fluid were all at the same temperature as the environment.

The variations of the cutter temperature at a rotation speed of $100 \mathrm{rpm}$ are shown in Fig. 10a. The environmental temperature was approximately $-9{ }^{\circ} \mathrm{C}$. The temperature increases rapidly when drilling starts and then fluctuates greatly with the alternation of rock particles and ice in the samples. It is found that the temperature increases as the drill load increases (Fig. 10b). As the drill load increases from 450 to $1200 \mathrm{~N}$, the maximum temperature difference increases from 3.67 to $5.96{ }^{\circ} \mathrm{C}$.

The penetration rate increases with an increase in the rotation speed because more cuttings are produced per unit time. The heat generated in drilling correspondingly increases as shown in Fig. 11a. The maximum temperature difference of the cutter increases from 4.17 to $6.21{ }^{\circ} \mathrm{C}$ when the rotation speed increases from 50 to $200 \mathrm{rpm}$ (Fig. 11b).

\section{Conclusions}

(1) The penetration rate fluctuates greatly when drilling in debris-rich ice due to the difference in hardness and strength between ice and rock. Though the penetration rate of the carbide drill bit is far slower than that of the PDC drill bits under the same conditions, both the carbide and PDC drill bits can achieve high penetration rates in debris-rich ice with low drill loads of 500-1200 $\mathrm{N}$ and rotation speeds of 50-200 rpm.

(2) For all tested types of drill bits, the maximum torque is no more than $45 \mathrm{Nm}$, and the power consumption is less than $0.8 \mathrm{~kW}$, which are acceptable for the existing electromechanical drills.

(3) The temperature rise of the cutter caused by frictional heat in debris-rich ice is quite high, and the maximum temperature rise can reach $6.21{ }^{\circ} \mathrm{C}$ under the tested conditions. This can result in ice chips melting, which may cause the drill to freeze into the hole. Both reduction of the heat generated during debris-rich ice drilling and effective cooling of the near-bottom area need to be studied further. 


\section{Acknowledgments}

Authors thank anonymous reviewer for fruitful remarks and comments. This paper presents results of the research conducted under support of the National Science Foundation of China (projects No. 41106158 and No. 41576184), the Geological Survey of China (project No. 3R212W324424) and the Specialized Research Fund for the Doctoral Program of Higher Education of China (project No. 2011006112007).

\section{References}

Augustin L., Motoyama H., Wilhelms F., Johnsen S., Hansen S.B., Talalay P., Vasiliev N., 2007. Drilling comparison in "warm ice" and drill design comparison. Annals of Glaciology, 47: 73-78.

Azuma N., Tanabe I., Motoyama H, 2007. Heat generated by cutting ice in deep ice-core drilling. Annals of Glaciology, 47: 61-67.

Cao P.L., Yang C., Zheng Z.C., Wang R.S., Zhang N., Liu C.P., Hu Z.Y., Talalay P., 2014. Low-load diamond drill bits for subglacial bedrock sampling. Annals of Glaciology, 55(68): 124-130.

Che D.M., Han P.D., Guo P., Ehmann K., 2012. Issues in Polycrystalline diamond compact cutter-rock interaction from a metal machining point of view Part I: Temperature, stresses, and forces. Journal of manufacturing science and engineering. 134(6): 064001-1-10.

Gow A.J. and Meese D.A., 1996. Nature of basal debris in the GISP2 and Byrd ice cores and its relevance to bed processes. Annals of Glaciology, 22: 134-140.

Green J., B. Koci, J. Kyne,2007. Koci drill for drilling in ice, sand and rock: drill requirements, design, performance, difficulties. Ann. Glaciol. 47, 105-108.

Gundestrup, N.S., Johnsen, S.J., Hansen, S.B., Shoji, H., Talalay, P., Wilhelms, F., 2002. Sticking deep ice core drills: Why and how to recover. Mem. Natl Inst. Polar Res., Special Issue 56, 181-195.

Haeberli W., B. Hallet, L. Arenson, R. Elconin, O. Humlum, A. Kääb, V. Kaufmann, B. Ladanyi, N. Matsuoka, S. Springman and D. 
Vonder Mühll (2006). Permafrost creep and rock glacier dynamics. Permafrost and Periglac. Process. 17: 189-214.

Hansen S.E., Nyblade A.A., Heeszel D.S., Wiens D.A., Shore P., Kanao M., 2010. Crustral structure of the Gamburtsev Mountains,

East Antarctica, from S-wave receiver functions and Rayleigh wave phase velocities. Earth and Planetary Science Letters, 300:

395-401.

Kudryashov B.B., Vasiliev N.I., Talalay P.G., 1994. KEMS-112 electromechanical ice core drill. Mem. Natl Inst. Polar Res., Special Issue 49: 5-8.

Loui J.P. and Karanam U.M.R.. 2005. Heat transfer simulation in drag-pick cutting of rocks. Tunnelling and underground space technology, 20: 263-270.

Motoyama, H. , 2007. The second deep ice coring project at Dome Fuji, Antarctica. Sci. Drilling, 5: 41-43.

Popp T.J., Hansen S.B., Sheldon S.G., Schwander J., Johnson J.A., 2014. Drilling into debris-rich basal ice at the bottom of the NEEM (Greenland) borehole. Annals of Glaciology, 55(68): 199-206.

Saito, T. and Yoshikawa K., 2008. Portable drilling for frozen coarse-grained material, Ninth International Conference on Permafrost, Fairbanks, 1-6.

Sellmann, P.V. and Mellor M., 1986. Drill bits for frozen fine-grained soil. US Army Cold Regions Research and Engineering Laboratory, CRREL special Report:86-87.

Sellmann, P.V. and Brockett B., 1988. Evaluation of several auger bits in frozen fine-grained soils, asphalt and concreat. US Army Cold Regions Research and Engineering Laboratory, CRREL special Report:88-8.

Talalay P.G., 2013. Subglacial till and bedrock drilling. Cold Regions Science and Technol., 86: 142-166.

Talalay P.G., 2003. Power consumption of deep ice electromechanical drills. Cold regions science and technology, 37: 69-78.

Truffer M., Motyka R.J., Harrison W.D., Echelmeyer K.A., Fisk B., Tulaczyk S., 1999. Subglacial drilling at Black Rapids Glacier, Alaska, USA: Drilling Method and Sample Descriptions. Journal of Glaciology, 45(151): 495-505.

Ueda H.T. and Garfield D.E., 1968. Drilling through the Greenland ice sheet. Cold Regions Research and Engineering Laboratory, Special Report 126: 1-15. 
Wang, D., He Y.X., 2014. Geological drilling handbook. Central South University Press, 244-282.

Wang, Z.W., J. Collins, and S.L Huang. 1994. Low power diamond rock coring parameters. Ice Drilling Technology, Proc. of the Fourth Int. Workshop on Ice Drilling Technology, Tokyo, April 20-23. Mem. Natl. Inst. Polar Res. 49, 99-112. 


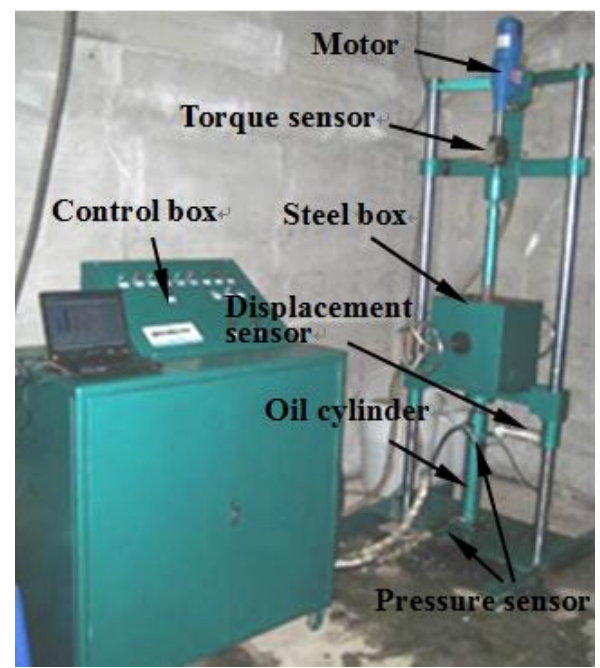

Fig. 1 Drill bit test stand 

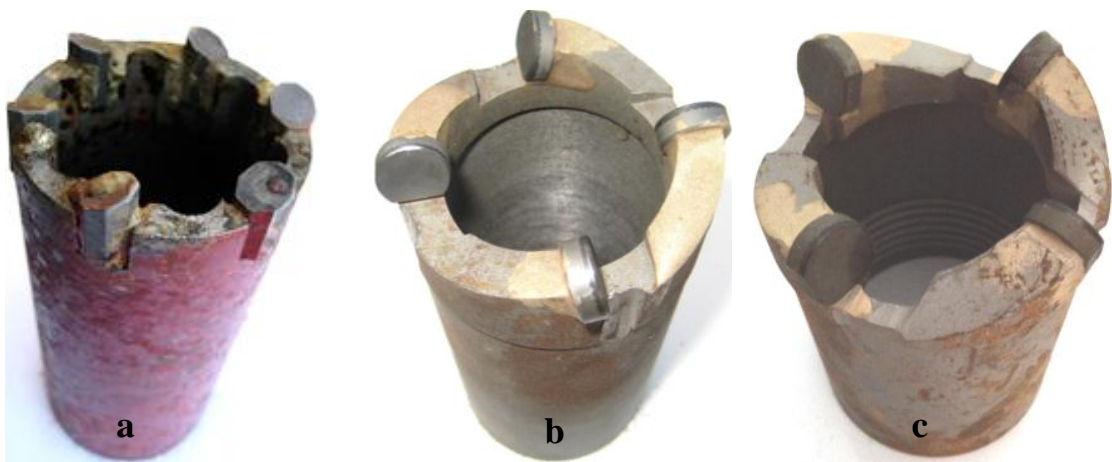

Fig. 2 Tested drill bits: (a) Carbide drill bit. (b) PDC drill bit with round compact. (c)PDC drill bit with square compact 

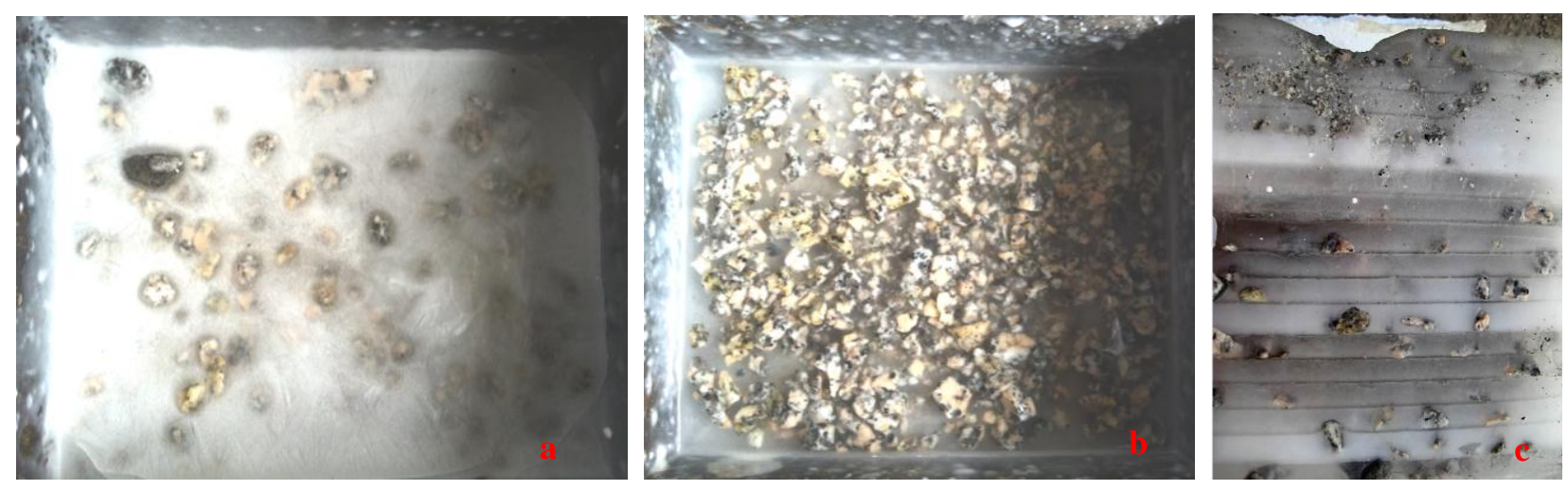

Fig. 3 Samples with different rock contents: (a) 10\% rock particles; (b) $\sim 30 \%$ rock particles; (c) profile section of the sample with $10 \%$ rock content 

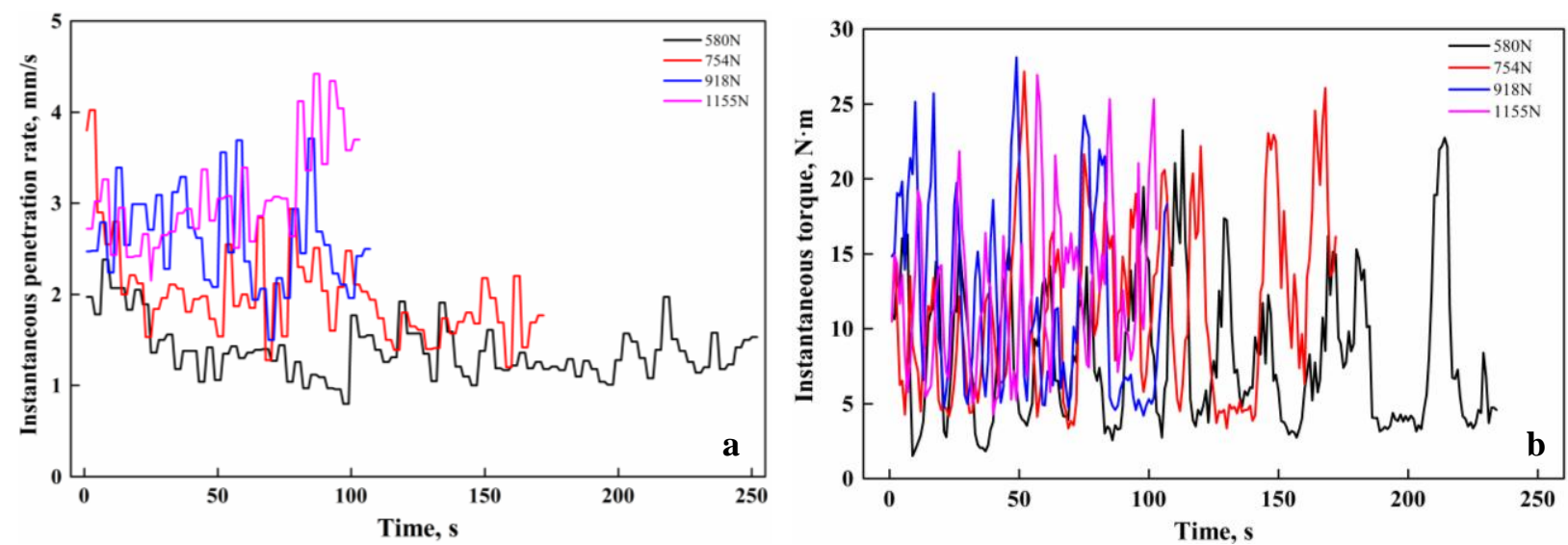

Fig. 4 Drilling parameters with carbide drilling bit: (a) instantaneous penetration rate; (b) instantaneous torque moment 

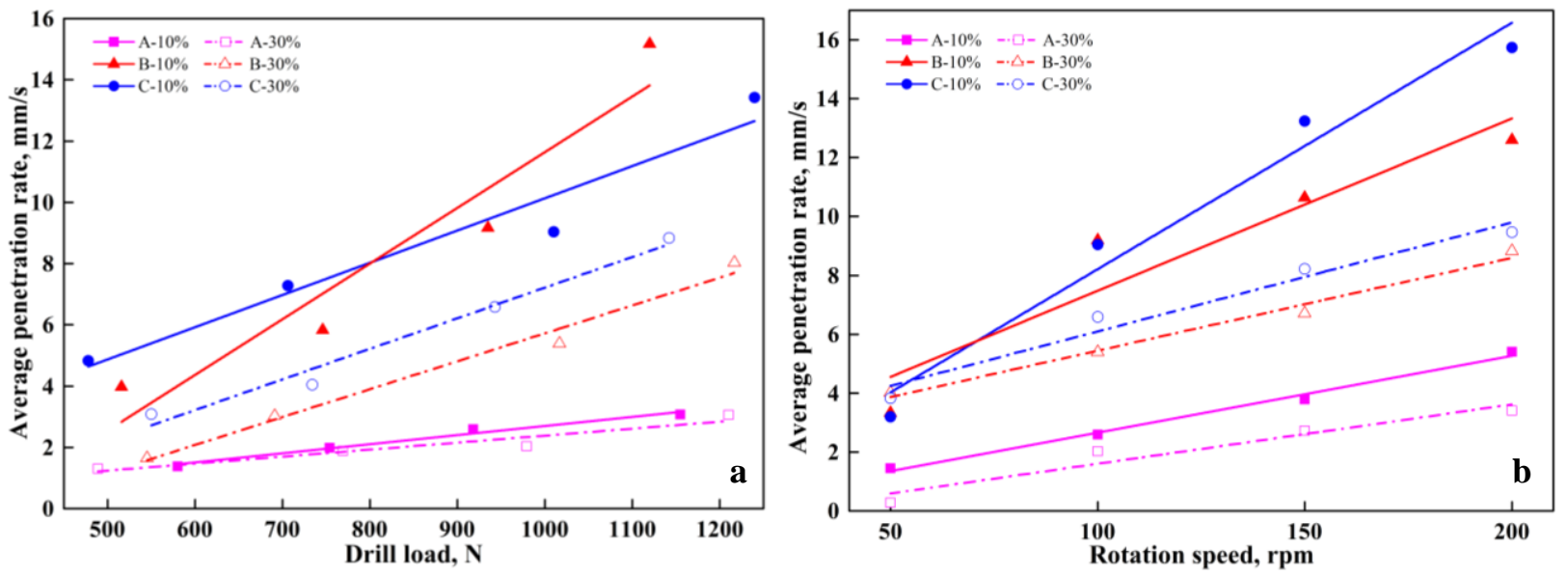

Fig. 5 (a) Penetration rate vs drill load; (b) Penetration rate vs rotation speed. 

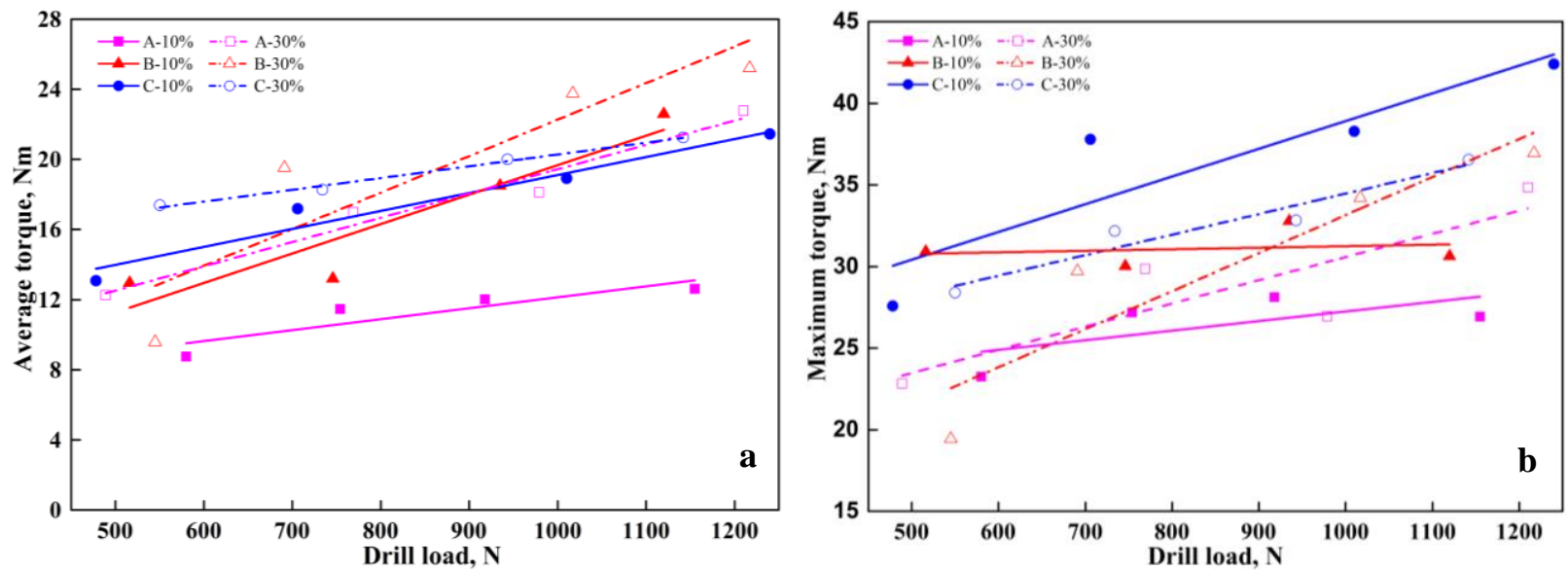

Fig. 6 (a) Average torque vs drill load; (b) Maximum torque vs drill load. 

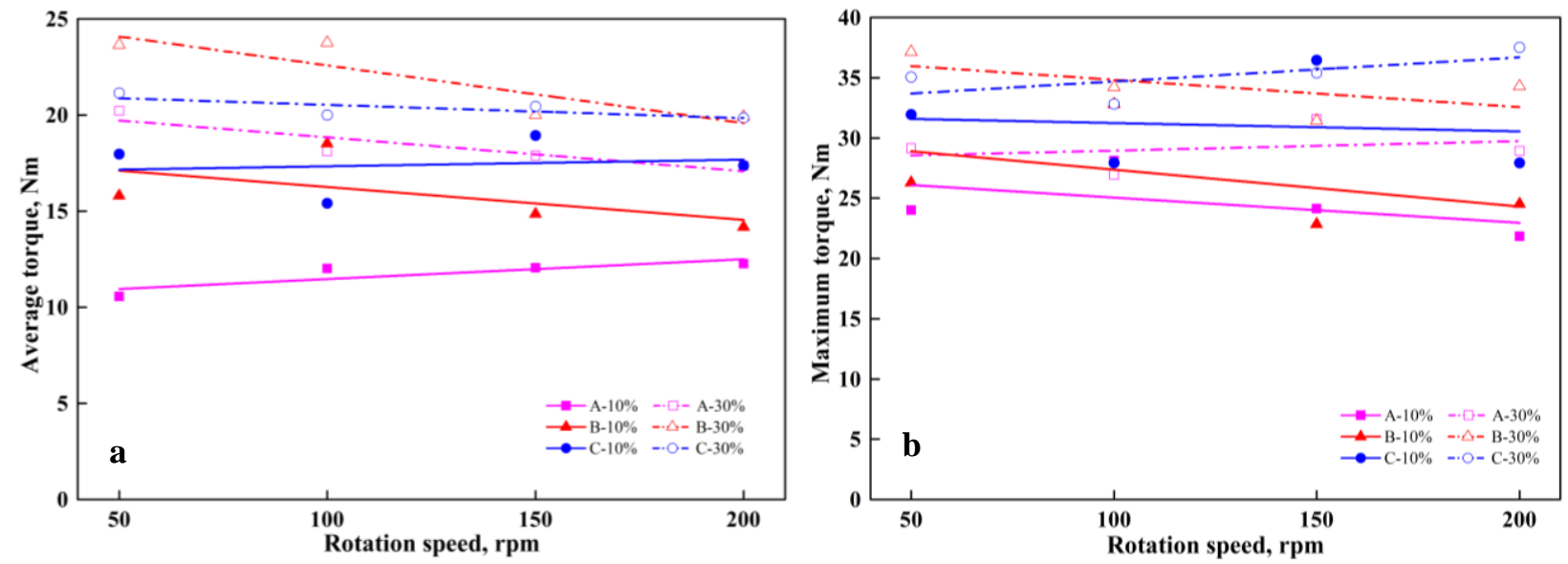

Fig. 7 (a) Average torque vs rotation speed; (b) Maximum torque vs rotation speed. 

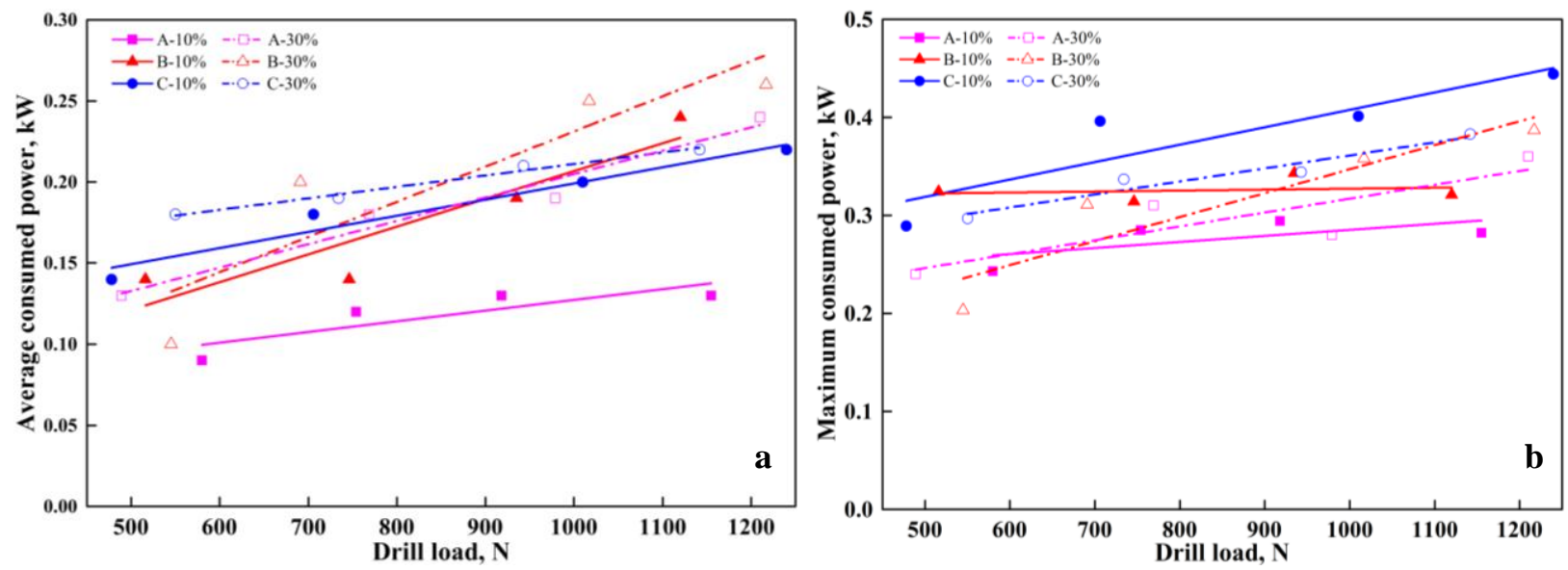

Fig. 8 (a) Average power consumption vs drill load; (b) Maximum power consumption vs drill load. 

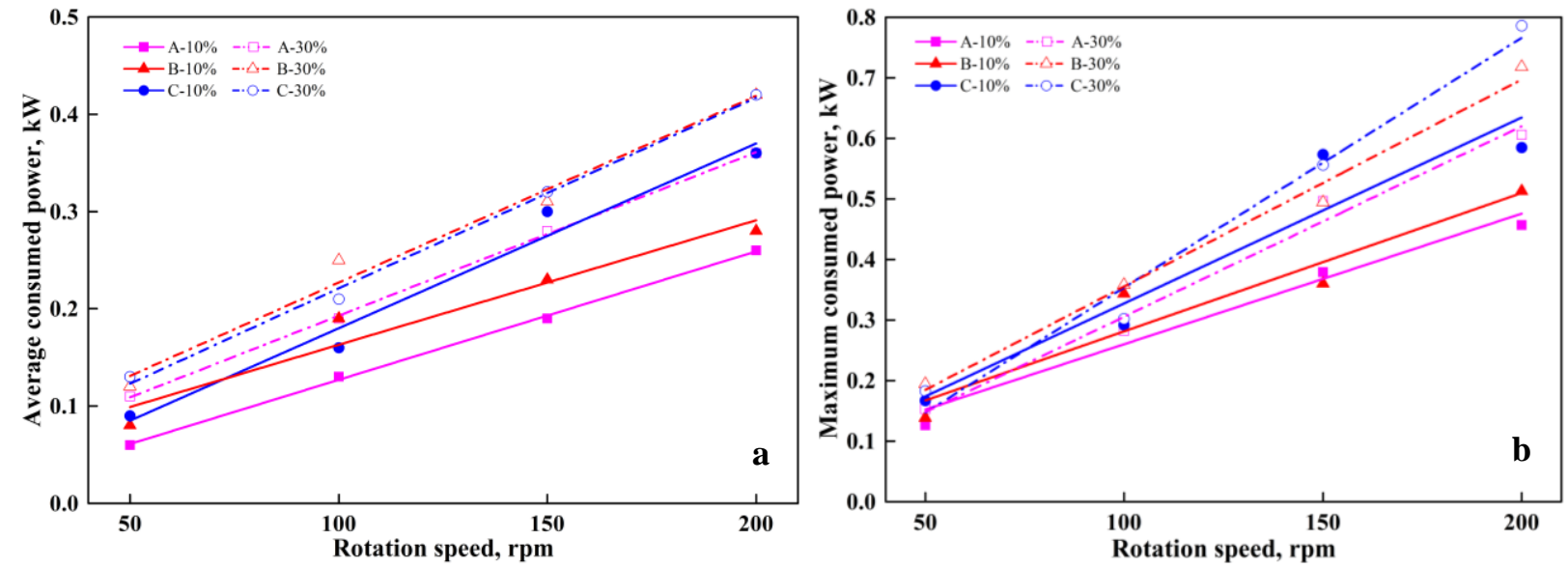

Fig. 9 (a) Average power consumption vs rotation speed; (b) Maximum power consumption vs rotation speed. 

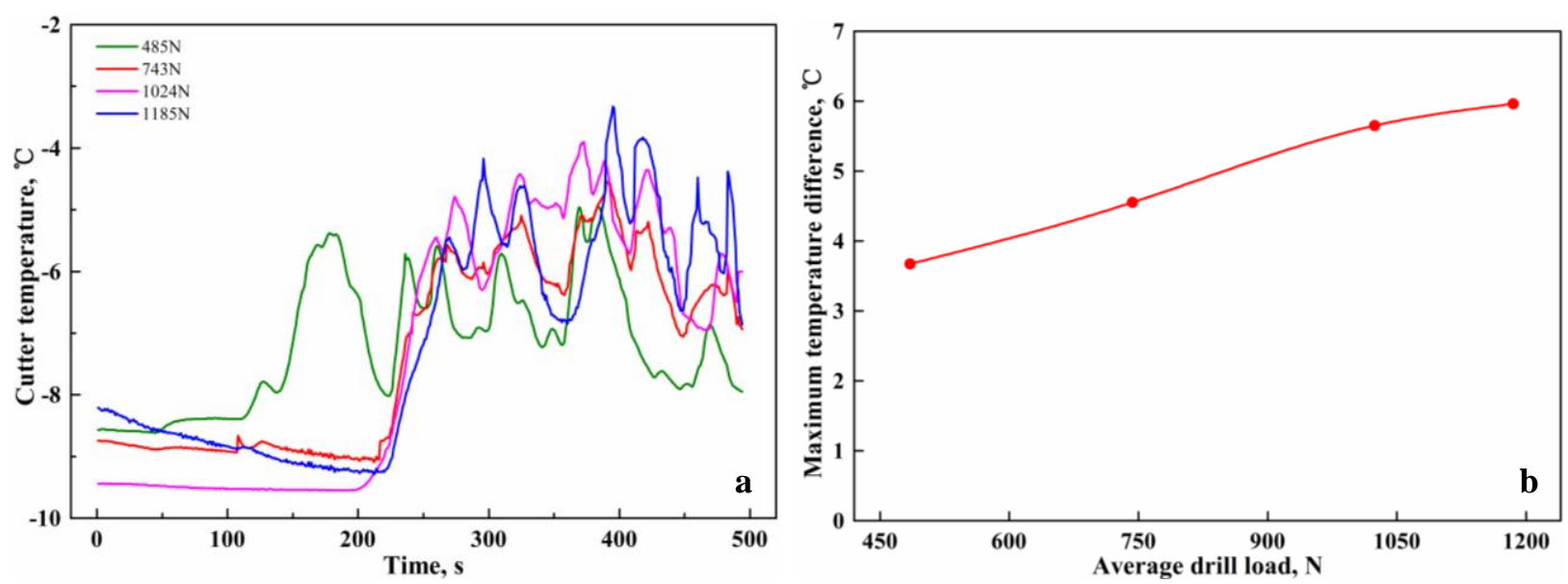

Fig. 10(a) Cutter temperature vs drill load; (b) Maximum temperature difference vs drill load.
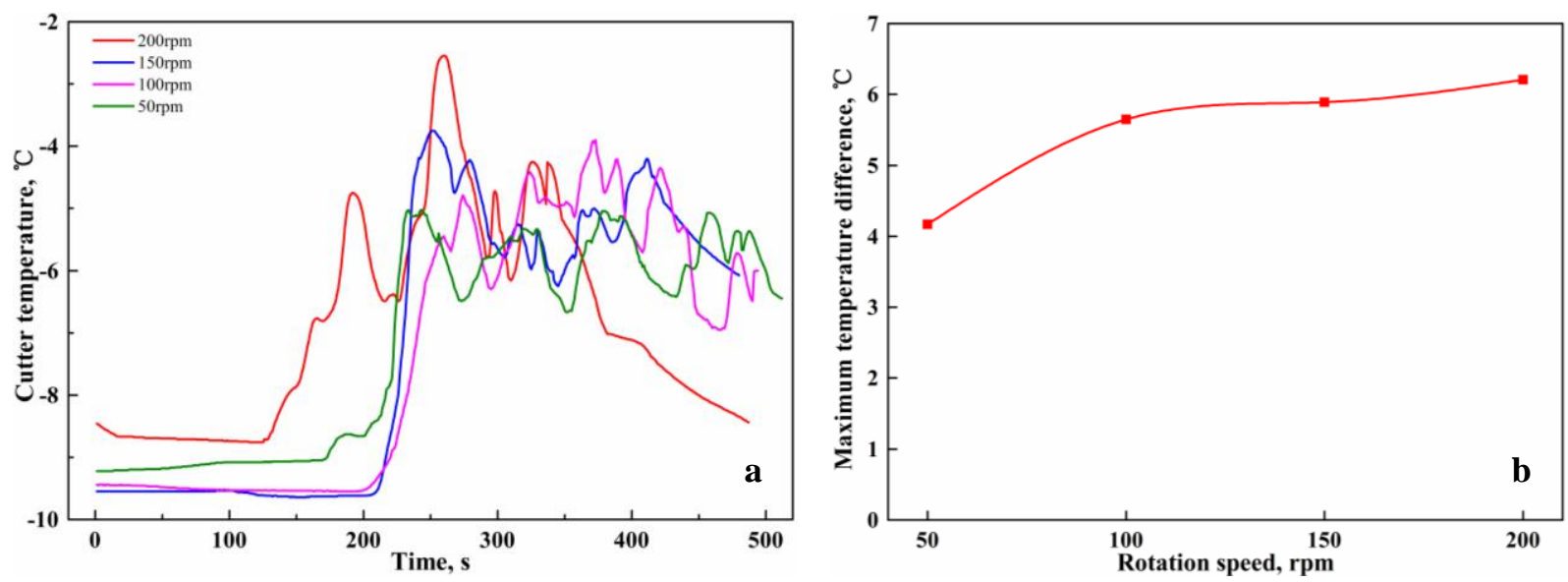

Fig. 11(a) Cutter temperature vs rotation speed; (b) Maximum temperature difference vs rotation speed. 
Table 1 Parameters of tested drill bits

\begin{tabular}{|l|l|l|l|l|l|l|}
\hline Index & Bits type & Cutter shape & $\begin{array}{l}\text { Outer/inner diameter } \\
\text { of the cutters, } \mathbf{m m}\end{array}$ & $\begin{array}{l}\text { Thickness of work } \\
\text { layer, } \mathbf{m m}\end{array}$ & $\begin{array}{l}\text { Rake angle, } \\
\text { deg. }\end{array}$ & $\begin{array}{l}\text { Relief angle, } \\
\text { deg. }\end{array}$ \\
\hline A & Carbide & Octagonal & $60 / 41$ & Not applicable & 0 & 25 \\
\hline B & PDC & Round & $63.5 / 37.5$ & 2 & -15 & 15 \\
\hline C & PDC & Semi-round & $60 / 41$ & 2 & -15 & 15 \\
\hline
\end{tabular}

